\title{
Soy $\beta$-Conglycinin Peptide Attenuates Obesity and Lipid Abnormalities in Obese Model OLETF Rats
}

\author{
Satoshi Wanezaki ${ }^{1}$, Shintaro Saito ${ }^{2}$, Nao Inoue ${ }^{3}$, Nobuhiko Tachibana ${ }^{1}$, \\ Bungo Shirouchi ${ }^{4}$, Masao Sato ${ }^{4}$, Teruyoshi Yanagita ${ }^{5}$, and Koji Nagao ${ }^{2 *}$ \\ ${ }^{1}$ Basic Research Institute, R\&D, Fuji Oil Co., Ltd., Kinunodai 4-3, Tsukubamirai-shi, Ibaraki 300-2497, JAPAN \\ ${ }^{2}$ Department of Biological Resource Science, Saga University, Honjo-1, Saga-shi, Saga 840-8502, JAPAN \\ ${ }^{3}$ Faculty of Agriculture, Yamagata University, Wakaba-machi 1-23, Tsuruoka-shi, Yamagata 997-8555, JAPAN \\ ${ }^{4}$ Department of Bioscience and Biotechnology, Graduate School, Kyushu University, Motooka-744, Nishi-ku, Fukuoka 819-0395, JAPAN \\ ${ }^{5}$ Faculty of Health and Social Welfare Sciences, Nishikyushu University, Ozaki 4490-9, Kanzaki, Saga 842-8585, JAPAN
}

\begin{abstract}
We previously reported that soy $\beta$-conglycinin ( $\beta C G)$ improves obesity-induced metabolic abnormalities, but not obesity, in obese model Otsuka Long-Evans Tokushima fatty (OLETF) rats. In the present study, we aimed to investigate the effects of $\beta C$ G-derived peptide consumption on obesity and lipid abnormality in OLETF rats. To this end, wild-type Long-Evans Tokushima Otsuka and OLETF rats were provided a normal diet containing $20 \%$ casein for four weeks as a control. In addition, we prepared $\beta C G$ peptide by enzymatic hydrolysis, and OLETF rats were fed a diet in which half of the casein was replaced by $\beta C G$ peptide ( $\beta C G$ peptide group). Consequently, rats in the $\beta C G$ peptide group showed decreased abdominal white adipose tissue weight and lipid content (serum and liver triglycerides, and serum and liver cholesterol) compared to control OLETF rats. Further analysis demonstrated that $\beta C$ G peptide consumption decreased lipogenic enzyme activity and increased lipolytic enzyme activity in the liver of OLETF rats. In addition, suppressive effects on both synthesis and absorption of cholesterol were observed in $\beta C G$ peptide-fed OLETF rats. These findings suggest that peptidization of $\beta C G$ enhanced the anti-obese and hypolipidemic effects of $\beta C G$.
\end{abstract}

Key words: $\beta C G$ peptide, soy protein, obesity, OLETF, lipogenesis, lipolysis

\section{Introduction}

The metabolic syndrome is known to increase cardiovascular morbidity and mortality, and central obesity is the key component of its development ${ }^{1-3)}$. Although the pathogenesis of metabolic syndrome is complicated, lipid abnormality is proposed as a feature of metabolic syndrome $^{1-3)}$. Many studies suggested that plant proteins could be important modulators of the risks associated with this syndrome ${ }^{4,5)}$. For example, several studies have shown that dietary soy protein reduces cholesterol and triglyceride (TG) levels in animals and humans ${ }^{4-8)}$. Moreover soy $\beta$-conglycinin ( $\beta \mathrm{CG}$ ), a soybean storage protein, has been reported to exert physiological effects such as promoting lipid lowering effects and preventing obesity in several animal models ${ }^{9-13)}$. However, physiological functions of $\beta C G$ in non-high-fat or non-high-cholesterol diet-fed rodents have not been fully evalutated, and almost all of previous studies have been conducted with diets in which all dietary protein was replaced by $\beta C G$ even though its es- sential amino acids are somewhat insufficient in animals growth $^{9-13)}$.

Otsuka Long-Evans Tokushima fatty (OLETF) rats develop multiple metabolic and hormonal abnormalities that shares many features with human obesity ${ }^{14-16)}$. In addition, these animals exhibit hyperphagia due to a cholecystokinin receptor deficiency, and become obese even by consuming a normal diet(e.g., AIN-76; 7\% fat) ${ }^{17-19)}$. Accordingly, OLETF rats have been suggested as s good model for obesity-induced metabolic dysfunction. We previously reported that the replacement of $10 \%$ casein with $\beta C G$ in non-high fat AIN-76 diet improves hepatomegaly and hepatic lipid accumulation, but not obesity, in obese model OLETF rats ${ }^{19)}$.

Since it has been previously reported that peptides or protein hydrolysates exhibit greater bioactivity than intact proteins or amino acid mixtures ${ }^{20,21)}$, bioactive peptides have been produced in vitro through chemical or enzymatic hydrolysis of several food proteins, to modify and

*Correspondence to: Koji Nagao, Department of Biological Resource Science, Saga University, Honjo-1, Saga-shi, Saga 840-8502, JAPAN

E-mail: knagao@cc.saga-u.ac.jp

Accepted February 14, 2020 (received for review January 14, 2020)

Journal of Oleo Science ISSN 1345-8957 print / ISSN 1347-3352 online

http://www.jstage.jst.go.jp/browse/jos/ http://mc.manusriptcentral.com/jjocs 


\section{S. Wanezaki, S. Saito, N. Inoue et al.}

improve the physiological functions of dietary proteins ${ }^{21,22)}$. In soy protein, several bioactive peptides, including hypocholesterolemic, antihypertensive, antioxidant, and appetite suppressive peptides, are derived from its major constituents, glycinin and $\beta \mathrm{CG}^{23-26)}$. However, of the limited number of peptides reported to possess hypotrigliceridemic activity have been identified in hydrolyzed globin from animal blood ${ }^{27)}$. In the present study, we sought to evaluate the diversification and reinforcement of bioactivity of $\beta \mathrm{CG}$ by the artificial peptidization and investigate the effects of $\beta C G$-derived peptides on obesity and obesity-induced lipid abnormality in OLETF rats.

\section{Materials and Methods}

\subsection{Animals and diets}

All experiments were conducted according to the guidelines provided by the ethics committee for experimental animal care of Saga University (No. 22-042-1, 2013-2015). Six-week-old male OLETF and Long-Evans Tokushima Otsuka(LETO) wild-type rats were purchased from Hoshino Laboratory Animals, Inc. (Ibaraki, Japan), and housed individually in metal cages in a temperature-controlled room $\left(24^{\circ} \mathrm{C}\right)$ on a $12 \mathrm{~h}$ light/dark cycle. After an adaptation period of one peak on a powder chow diet (CE-2; Clea Japan, Tokyo, Japan), the rats were fed with one of the two diets, as shown in Table 1. LETO and control OLETF rats $(n=6$ of each) were maintained on the same casein-based diet, while a second group of OLETF rats (n $=6$ ) were fed a similar diet, except that the casein and sucrose in the diet were replaced with $11.43 \%(\mathrm{w} / \mathrm{w}) \beta \mathrm{CG}$ peptide. $\beta C G$ peptide was prepared from intact $\beta C G$ (Lipoff,

Table 1 Composition of experimental diets.

\begin{tabular}{lccc}
\hline \multirow{2}{*}{ Ingredients } & & Control & $\beta C G$ peptide \\
\cline { 3 - 4 } & LETO & \multicolumn{2}{c}{ OLETF } \\
\hline & \multicolumn{2}{c}{$(\%)$} \\
Casein & 20.0 & 20.0 & 10.0 \\
$\beta C G$ peptide & - & - & $11.43^{\dagger}$ \\
Cornstarch & 15.0 & 15.0 & 15.0 \\
Cellulose & 5.0 & 5.0 & 5.0 \\
Mineral mixture* & 3.5 & 3.5 & 3.5 \\
Vitamin mixture* & 1.0 & 1.0 & 1.0 \\
DL-methionine & 0.3 & 0.3 & 0.3 \\
Choline bitartrate & 0.2 & 0.2 & 0.2 \\
Corn oil & 7.0 & 7.0 & 7.0 \\
Sucrose & 48.0 & 48.0 & 46.57 \\
\hline
\end{tabular}

$\beta C G$ : $\beta$-Conglycinin

$\dagger$ Nitrogen content is equal to $10 \%$ casein

* AIN-76
Fuji oil Co., Osaka, Japan) as follows: $\beta C G$ was dissolved in water at $5 \%$ and hydrolyzed by pepsin $(1.0 \%$ per substrate) for $2 \mathrm{~h}$ under acidic conditions $(\mathrm{pH} 2.0)$ at $37^{\circ} \mathrm{C}$. Next, the $\beta C G$ solution was degraded for $2 \mathrm{~h}$ using trypsin ( $1.7 \%$ per substrate) and chymotrypsin $(0.03 \%$ per substrate) under neutral conditions $(\mathrm{pH} 8.0)$ at $37^{\circ} \mathrm{C}$. After enzymatic hydrolysis, the $\beta \mathrm{CG}$ solution was heated at $80^{\circ} \mathrm{C}$ for $10 \mathrm{~min}$ and centrifuged at $10,000 \times \mathrm{g}$ for $10 \mathrm{~min}$. The supernatant (containing $\beta C G$ peptide) was recovered, freeze-dried, and powdered and used in the experiment. The amino acid composition of $\beta C G$ peptide was similar to intact $\beta \mathrm{CG}$, and the molecular weight distribution of $\beta \mathrm{CG}$ peptide, estimated by gel filtration, ranged from 20015,000 (the peak molecular weight distribution was approximately 5,000). At the end of the experimental period (four weeks) and after a 9-h starvation, while under anesthesia, blood was collected from the abdominal aorta into a syringe. Serum was obtained by centrifugation $(1,900 \times \mathrm{g}$, $15 \mathrm{~min}, 4^{\circ} \mathrm{C}$ ) and stored at $-80^{\circ} \mathrm{C}$ until further analysis. Abdominal (perirenal, epididymal, and omental)white adipose tissues (WAT) and liver were immediately were harvested, weighed, and stored at $-80^{\circ} \mathrm{C}$.

\subsection{Measurement of serum parameters}

Serum triglyceride (TG), cholesterol, phospholipid, glucose, and non-esterified fatty acids (NEFA) levels were measured using commercial enzyme assay kits (Wako Pure Chemicals).

Biomarkers related to cholesterol metabolism, such as lathosterol, campesterol, and $\beta$-sitosterol, in serum were assayed by a gas chromatography-flame ionization detector (GC-FID) system (GC-17A; Shimadzu, Tokyo, Japan) equipped with a capillary column $\left(\mathrm{SPB}^{\mathrm{TM}}-1,60 \mathrm{~m} \times 0.25 \mathrm{~mm}\right.$ i.d., $0.25 \mu \mathrm{m}$ thickness, SUPELCO, Bellefonte, PA, USA) using $5 \alpha$-cholestane (Sigma Aldrich Japan) as an internal standard. In brief, to $250 \mu \mathrm{L}$ of each serum sample was added $25 \mu \mathrm{g}$ of $5 \alpha$-cholestane. Samples were saponified with ethanolic $\mathrm{KOH}$ and then the sterols were extracted. The extracted sterols were converted to trimethylsilyl (TMS) ethers using the TMS derivatization reagent(BSTFA + TMCS, 99:1, SUPELCO) and then injected to the GC-FID system. The temperatures of the injection port and detector were set at $300^{\circ} \mathrm{C}$, respectively. The column temperature was set at $275^{\circ} \mathrm{C}$. Helium (purity $>99.995 \%$ ) was used as the carrier gas. The sterol species were identified by comparison with the retention times of the internal standard and the reference standards (lathosterol, campesterol, and $\beta$-sitosterol from Sigma Aldrich Japan)after TMS derivatization.

\subsection{Measurement of lipid levels in the liver}

Hepatic lipid was extracted from the liver by the method described by Folch et $a l .{ }^{28)}$. Hepatic concentrations of TG and phospholipid were measured according to the methods 
Table 2 Effects of $\beta C G$ peptide on growth parameters.

\begin{tabular}{lccc}
\hline & & Control & $\beta C G$ peptide \\
\cline { 3 - 4 } & LETO & \multicolumn{2}{c}{ OLETF } \\
\hline Initial B.W. (g) & $116 \pm 2$ & $124 \pm 2^{*}$ & $124 \pm 1$ \\
Final B.W. (g) & $271 \pm 2$ & $307 \pm 3^{*}$ & $307 \pm 3$ \\
B.W. gain (g) & $154 \pm 3$ & $183 \pm 4^{*}$ & $184 \pm 3$ \\
Food intake (g) & $154 \pm 3$ & $183 \pm 4^{*}$ & $184 \pm 3$ \\
$\begin{array}{l}\text { Food efficiency } \\
\text { (g gain/g intake) }\end{array}$ & $0.334 \pm 0.006$ & $0.324 \pm 0.005$ & $0.324 \pm 0.005$ \\
Liver weight & & & \\
(g/ 100 g B.W.) & $3.45 \pm 0.07$ & $3.44 \pm 0.08$ & $3.35 \pm 0.06$ \\
\hline
\end{tabular}

* shows significant difference at $p<0.05$ vs LETO.

described by Fletcher et $a{ }^{29)}$ and Rouser et $a l .{ }^{30)}$, respectively. Hepatic cholesterol concentration was analyzed using the Cholesterol E-Test Wako (Wako Pure Chemical Industries, Ltd.).

\subsection{Assay for hepatic enzyme activity}

A piece of liver from each rat was homogenized in 6 volumes of a $0.25 \mathrm{M}$ sucrose solution containing $1 \mathrm{mM}$ ethylenediaminetetraacetic acid in a $10 \mathrm{mM}$ Tris-HCl buffer ( $\mathrm{pH}$ 7.4). After the nuclear fractions were precipitated, the supernatants were centrifuged at $10,000 \times \mathrm{g}$ for $10 \mathrm{~min}$ at $4{ }^{\circ} \mathrm{C}$ to obtain mitochondrial fractions. The resulting supernatants were recentrifuged at $125,000 \times \mathrm{g}$ for $60 \mathrm{~min}$ to precipitate microsomes, and the remaining supernatant constituted the cytosol fraction. The specific enzymatic activity of two enzymes involved in de novo triglyceride synthesis - fatty acid synthase (FAS), malic enzyme and glucose 6-phosphate dehydrogenase (G6PDH) - in the cytosomal fraction, as well as that of the fatty acid translocation enzyme carnitine palmitoyltransferase (CPT) in the mitochondrial fraction, were determined as described elsewhere $^{31-34)}$. The protein concentration of each fraction was determined according to the Lowry method ${ }^{35)}$, with bovine serum albumin used as the standard.

\subsection{Statistical analysis}

The data are presented as the means \pm standard error (SE). In order to check a state as a model for obesity, mean differences between LETO and control OLETF rats were determined by the student's t-test (KaleidaGraph ver.4; Synergy Software, Reading, PA, USA). To confirm the efficacy of $\beta C G$ peptide for OLETF rats, mean differences between control OLETF and $\beta$ CG peptide groups were determined by the student's t-test. $P<0.05$ was considered statistically significant.

\section{White adipose tissue (g/100g B.W.)}

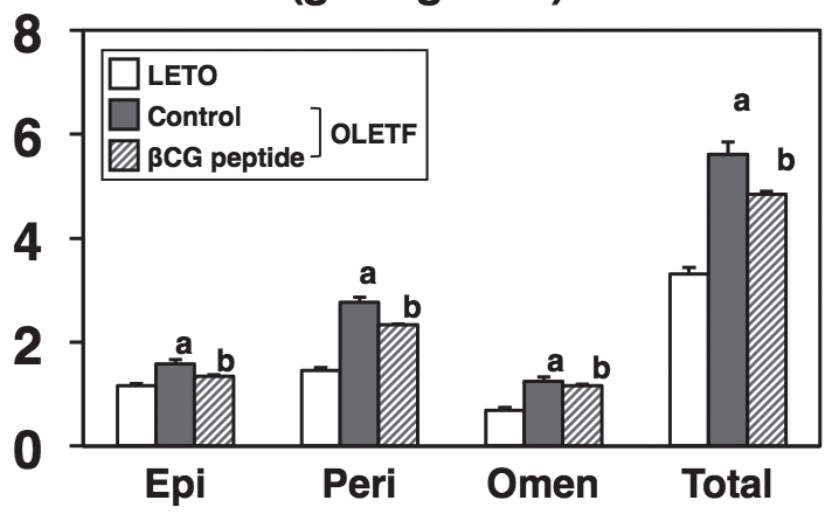

Fig. 1 Effect of $\beta C G$ peptide on white adipose tissue weights.

Rats were fed the Control diet or $\beta C G$ peptide diet for four weeks. Values are expressed as the mean \pm standard error for six rats. See Table 1 for composition of diets. ${ }^{a}$ A significant difference was observed between LETO and control diet-fed OLETF rats (at $p<0.05$ ). ${ }^{\mathrm{b}}$ A significant difference was observed between control and $\beta C G$ peptide diets in OLETF rats $(p<0.05)$.

\section{Results and Discussion}

This study evaluated whether the consumption of $\beta C G$ peptide could affect obesity and lipid abnormality in obese model OLETF rats.

\subsection{Effect of $\beta C G$ peptide on growth parameter}

Accompanied by higher food intake, weight of WATs increased in control diet-fed OLETF rats compared to LETO rats (Table 2, Fig. 1). Although there was no difference in the weight of liver, the weight of epididymal and perirenal abdominal WATs in the $\beta C G$ peptide group was significantly lower than that in the control group of OLETF rats (Table 2, Fig. 1). Recently, Kawabeta et al. reported that the re- 


\section{S. Wanezaki, S. Saito, N. Inoue et al.}

Table 3 Effects of $\beta C G$ peptide on serum and liver parameters.

\begin{tabular}{lccc}
\hline & & Control & $\beta C G$ peptide \\
\cline { 3 - 4 } & LETO & \multicolumn{2}{c}{ OLETF } \\
\hline Serum parameters & & $118 \pm 10^{*}$ & $78.4 \pm 5.2^{\dagger}$ \\
TG (mg/dL) & $55.9 \pm 5.8$ & $169 \pm 6^{*}$ & $129 \pm 3^{\dagger}$ \\
CHOL (mg/dL) & $127 \pm 3$ & $227 \pm 5^{*}$ & $177 \pm 6^{\dagger}$ \\
PL (mg/dL) & $159 \pm 7$ & $193 \pm 12^{*}$ & $168 \pm 5$ \\
Glucose (mg/dL) & $152 \pm 9$ & $0.733 \pm 0.021^{*}$ & $0.660 \pm 0.044$ \\
NEFA (mEq/L) & $0.621 \pm 0.028$ & & \\
Liver parameters & & & $10.2 \pm 0.5^{\dagger}$ \\
TG (mg/g liver) & $8.50 \pm 0.68$ & $16.3 \pm 0.6^{*}$ & $3.26 \pm 0.08^{\dagger}$ \\
CHOL (mg/g liver) & $3.63 \pm 0.13$ & $3.75 \pm 0.14$ & $36.5 \pm 0.5$ \\
PL (mg/g liver) & $36.4 \pm 0.6$ & $37.2 \pm 0.7$ & \\
\hline
\end{tabular}

TG: triglyceride, CHOL: cholesterol, PL: phospholipid

NEFA: non esterified fatty acid

* shows significant difference at $p<0.05$ vs LETO.

$\dagger$ shows significant difference at $p<0.05$ vs Control.

placement of $10 \%$ casein with $\beta C G$ in high-starch AIN-93G diet lowers mesenteric adipose tissue weight in OLETF rats $^{36}$. Our previous study, however, the replacement of $10 \%$ casein with $\beta C G$ in high-sucrose AIN-76 diet could not affect WAT weights in OLETF rats ${ }^{19)}$. Collectively, these results suggest that physiological functions of $\beta C G$ are slightly difficult to evaluate on a high-sucrose diet and the anti-obesity effects of $\beta C G$ peptide diet are stronger than $\beta C G$ diet.

\subsection{Effect of $\beta C G$ peptide on lipids and glucose levels}

Lipid levels (TG, cholesterol and phospholipids) in the liver and serum, serum glucose and serum NEFA were significantly higher in the control OLETF group than in the LETO group (Table 3 ). There were also significant differences in the levels of serum and liver components between the groups in OLETF rats (Table 3). Although serum glucose and NEFA levels did not differ, TG, cholesterol and phospholipid levels were lower in $\beta$ CG peptide-fed rats than those in control. In addition, lower hepatic TG and cholesterol levels were observed in the $\beta C G$ peptide group than the control group in OLETF rats. Previous studies showed that $\beta C G$ did not decrease serum TG levels of OLETF rats ${ }^{19,36}$. Similarly, we observed that hypolipidemic effects were enhanced by the peptidization of $\beta C G$.

\subsection{Effect of $\beta C G$ peptide on triglyceride metabolism}

To further examine the effect of $\beta C G$ peptide on the liver, hepatic enzymes related to TG metabolism were analyzed.

Activities of FAS, key enzymes in the regulation of FA de novo synthesis, and G6PDH and malic enzyme, which provide the NADPH required for fatty acid synthesis, were significantly higher in the liver of OLETF rats compared with LETO rats. In OLETF rats, malic enzyme (Fig. 2) activity was not different between the groups, but the activity of FAS and G6PDH were significantly lower in rats maintained on the $\beta C G$ peptide diet compared to the control OLETF rats (Fig. 2). These data suggest that $\beta C G$ peptide administration lowers TG levels through the suppression of hepatic lipogenesis in obese OLETF rats, which is consistent with previous studies ${ }^{19,36)}$.

The activity of CPT, a key enzyme of mitochondrial fatty acid $\beta$-oxidation, differed slightly between LETO and OLETF rats. However, in OLETF rats, CPT activity was markedly enhanced by $\beta C G$ peptide feeding in the mitochondrial fraction of the liver(Fig. 2). These results suggest that $\beta C G$ peptide administration alleviates hepatic TG accumulation partly through enhancement of lipolysis in the livers of obese OLETF rats. Additionally, given the results from previous studies using both AIN-76 and AIN-93G diet composition indicating that $\beta \mathrm{CG}$ feeding did not alter hepatic lipolytic enzyme activities in OLETF $\operatorname{rats}^{19,36)}$, it can be infered that $\beta C G$ gained additional bioactivity by the peptidization.

\subsection{Effect of $\beta C G$ peptide on cholesterol metabolism}

To gain insight into the effect of dietary $\beta C G$ peptide on cholesterol metabolism, we analyzed biomarkers related to cholesterol metabolism in the serum(Fig. 3). To evaluate whole-body cholesterol metabolism, cholesterol synthesis and absorption need to be measured. Lathosterol is a precursor of cholesterol de novo cholesterol synthesis, and its serum level can be used as an index of cholesterol synthesis in the body. Plant sterols, such as campesetrol and $\beta$-sitosterol, are sterol isomers that cannot be synthesized 
FAS
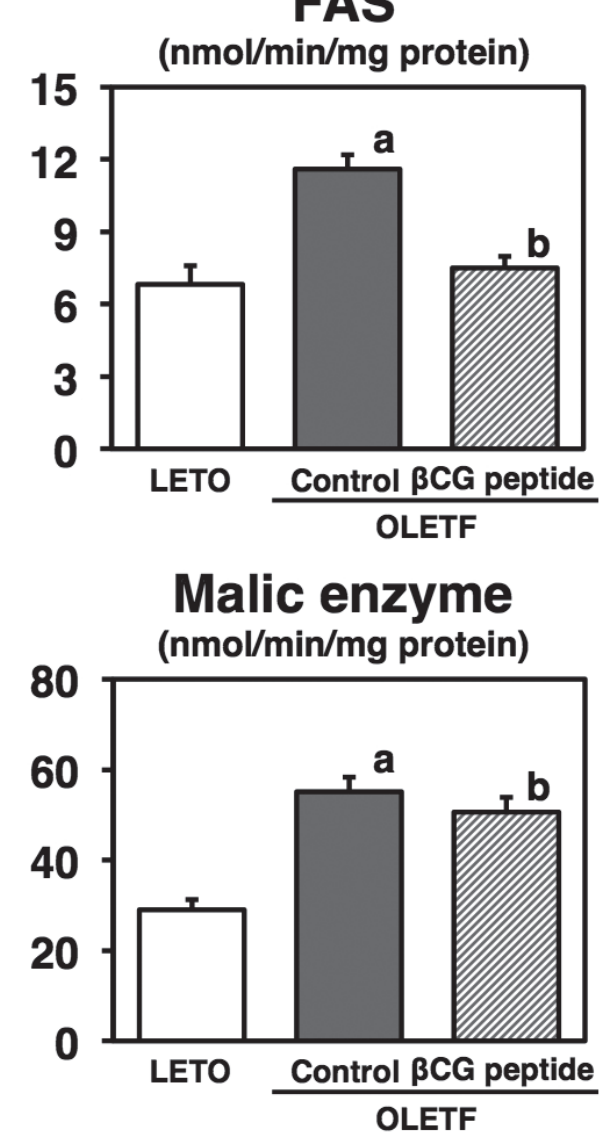
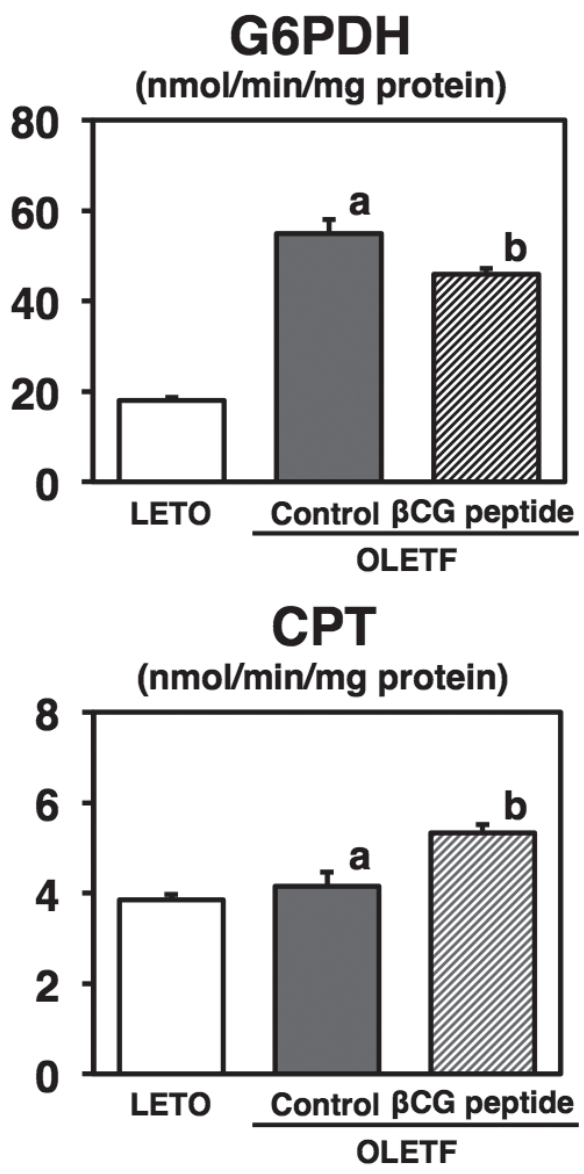

Fig. 2 Effect of $\beta$ CG peptide on hepatic enzyme activities.

Rats were fed the Control diet or $\beta C G$ peptide diet for four weeks. Values are expressed as the mean \pm standard error for six rats. See Table 1 for composition of diets. ${ }^{a}$ A significant difference was observed between LETO and control diet-fed OLETF rats $($ at $p<0.05)$. ${ }^{\mathrm{b}}$ A significant difference was observed between control and $\beta$ CG peptide diets in OLETF rats $(p<0.05)$.

in animal body and their presence in the serum showed positive correlations with the absorption rate of dietary sterols $^{37,38)}$.

Serum lathosterol levels were slightly higher in OLETF rats than LETO rats. In OLETF rats, serum lathosterol levels were significantly lower in rats on the $\beta C G$ peptide diet compared to the control OLETF rats (Fig. 3). These data suggest that $\beta C G$ peptide administration lowers cholesterol levels partly through the suppression of cholesterol synthesis in obese OLETF rats.

Serum plant sterol levels, the indices for cholesterol absorption, were significantly higher in OLETF rats than LETO rats. In OLETF rats, levels of serum plant sterols, campesterol and $\beta$-sitosterol, were significantly lower in rats on the $\beta C G$ peptide diet compared to the control OLETF rats (Fig. 3). These data suggest that suppression of cholesterol absorption by $\beta$ CG peptide contribute to a decrease in cholesterol levels in obese OLETF rats.

\section{Conclusions}

The present study shows that the dietary intake of $\beta C G$ peptide leads to an anti-obesity effect and alleviates lipid abnormality in OLETF rats. In particular, both hypolipogenic effect and enhanced lipolytic effects of $\beta \mathrm{CG}$ peptide in the liver may provide a mechanistic basis for the observed effects. Additionally, suppressive effects on both synthesis and absorption of cholesterol can be attributed to the hypocholesterolemic effect of $\beta C G$ peptide.

Although its enhancement mechanism has not yet been completely elucidated, soy protein hydrolysate exerts stronger lipid lowering effects than intact soy protein ${ }^{39,40)}$. Since previous studies reported that hydrolyzed soy protein is more rapidly and efficiently absorbed ${ }^{41)}$ and has higher lipolysis-stimulating ${ }^{39)}$ and antioxidant activities ${ }^{40)}$ than those of intact soy protein, we hypothesized that peptidizaion of $\beta C G$ exposes some bioactive amino acid $R$ groups or bioactive peptide sequences, conferring these properties. Further investigations are required to clarify the bioactive structures and biological mechanism of 
Synthesis marker
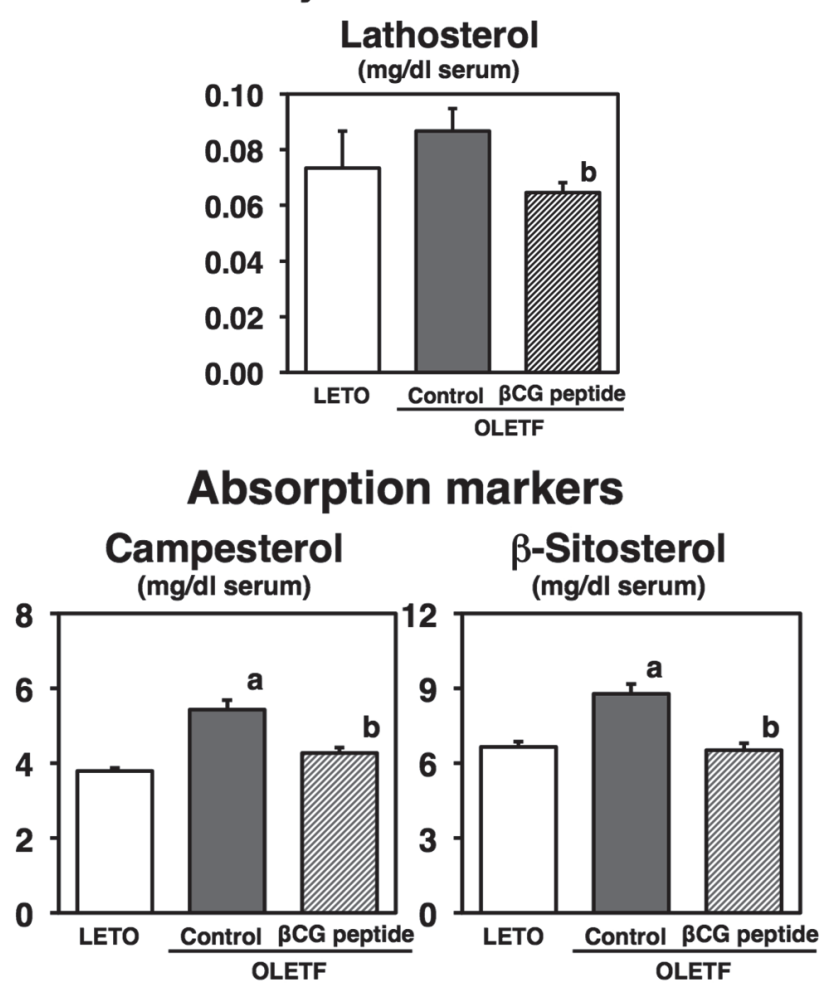

Fig. 3 Effect of $\beta C G$ peptide on levels of biomarkers related to cholesterol metabolism in serum.

Rats were fed the Control diet or $\beta C G$ peptide diet for four weeks. Values are expressed as the mean \pm standard error for six rats. See Table 1 for composition of diets. ${ }^{\text {a }}$ A significant difference was observed between LETO and control diet-fed OLETF rats $($ at $p<0.05)$. ${ }^{\mathrm{b}}$ A significant difference was observed between control and $\beta C G$ peptide diets in OLETF rats $(p<0.05)$.

actions of $\beta C G$ peptide to determine whether it can improve or prevent obesity-induced metabolic disorders in humans.

\section{Acknowledgments}

This work was supported by a research grant from the Japanese Ministry of Education, Culture, Sports, Science and Technology (JSPS KAKENHI Grant No. 23580173). We would like to thank Editage (www.editage.com) for English language editing.

\section{Conflict of Interests}

The authors declare no conflicts of interest associated with this manuscript.

\section{References}

1) Kissebah, A.H.; Krakower, G.R. Regional adiposity and morbidity. Physiol. Rev. 74, 761-811 (1994).

2) Formiguera, X.; Canton, A, Obesity: Epidemiology and clinical aspects. Best Pract. Res. Clin. Gastroenterol. 18, 1125-1146 (2004).

3) Nagao, K.; Yanagita, T. Bioactive lipids in metabolic syndrome. Prog. Lipid Res. 47, 127-146(2008).

4) Tovar, A.R.; Torres, N. The role of dietary protein on lipotoxicity. Biochim. Biophys. Acta 1801, 367-371 (2010).

5) Appel, L.J. The effects of protein intake on blood pressure and cardiovascular disease. Curr. Opin. Lipidol. 14, 55-59 (2003).

6) Sirtori, C.R.; Galli, C.; Anderson, J.W.; Arnoldi, A. Nutritional and nutraceutical approaches to dyslipidemia and atherosclerosis prevention: Focus on dietary proteins. Atherosclerosis 203, 8-17 (2009).

7) Sakono, M.; Yoshida, K.; Yahiro, M. Combined effects of dietary protein and fat on lipid metabolism in rats. $J$. Nutr. Sci. Vitaminol. (Tokyo)39, 335-343(1993).

8) Koba, K.; Liu, J.W.; Bobik, E. Jr.; Mills, D.E.; Sugano, M.; Huang, Y.S. Effect of phytate in soy protein on the serum and liver cholesterol levels and liver fatty acid profile in rats. Biosci. Biotechnol. Biochem. 67, 15-22 (2003).

9) Aoyama, T.; Kohno, M.; Saito, T.; Fukui, K.; Takamatsu, K.; Yamamoto, T.; Hashimoto, Y.; Hirotsuka, M.; Kito, M. Reduction by phytate-reduced soybean beta-conglycinin of plasma triglyceride level of young and adult rats. Biosci. Biotechnol. Biochem. 65, 1071-1075 (2001).

10) Tachibana, N.; Iwaoka, Y.; Hirotsuka, M.; Horio, F.; Kohno, M. Beta-conglycinin lowers very-low-density lipoprotein-triglyceride levels by increasing adiponectin and insulin sensitivity in rats. Biosci. Biotechnol. Biochem. 74, 1250-1255(2010).

11) Kohno, M.; Hirotsuka, M.; Kito, M.; Matsuzawa, Y. Decreases in serum triacylglycerol and visceral fat mediated by dietary soybean beta-conglycinin. J. Atheroscler. Thromb. 13, 247-255(2006).

12) Moriyama, T.; Kishimoto, K.; Nagai, K.; Urade, R.; Ogawa, T.; Utsumi, S.; Maruyama, N.; Maebuchi, M. Soybean beta-conglycinin diet suppresses serum triglyceride levels in normal and genetically obese mice by induction of beta-oxidation, downregulation of fatty acid synthase, and inhibition of triglyceride absorption. Biosci. Biotechnol. Biochem. 68, 352-359 (2004).

13) Yamazaki, T.; Kishimoto, K.; Miura, S.; Ezaki, O. Dietary $\beta$-conglycinin prevents fatty liver induced by a high-fat diet by a decrease in peroxisome proliferatoractivated receptor $\gamma 2$ protein. J. Nutr. Biochem. 23, 123-132(2012). 
14) Yagi, K.; Kim, S.; Wanibuchi, H.; Yamashita, T.; Yamamura, Y.; Iwao, H. Characteristics of diabetes, blood pressure, and cardiac and renal complications in Otsuka Long-Evans Tokushima Fatty rats. Hypertension 29, 728-735 (1997).

15) Takiguchi, S.; Taketa, Y.; Funakoshi, A.; Miyasaka, K.; Kataoka, K.; Fujimura, Y.; Goto, T.; Kono, A. Disrupted cholecystokinin type-A receptor (CCKAR)gene in OLETF rats. Gene 197, 169-175 (1997).

16) Hida, K.; Wada, J.; Zhang, H.; Hiragushi, K.; Tsuchiyama, Y.; Shikata, K.; Makino, H. Identification of genes specifically expressed in the accumulated visceral adipose tissue of OLETF rats. J. Lipid Res. 41, 1615$1622(2000)$.

17) Inoue, N.; Nagao, K.; Sakata, K.; Yamano, N.; Gunawardena, P.E.; Han, S.Y.; Matsui, T.; Nakamori, T.; Furuta, H.; Takamatsu, K.; Yanagita, T. Screening of soy protein-derived hypotriglyceridemic di-peptides in vitro and in vivo. Lipids Health Dis. 10, 85 (2011).

18) Inoue, N.; Nagao, K.; Nomura, S.; Shirouchi, B.; Inafuku, M.; Hirabaru, H.; Nakahara, N.; Nishizono, S.; Tanaka, T.; Yanagita, T. Effect of Vaccinium ashei reade leaf extracts on lipid metabolism in obese OLETF rats. Biosci. Biotechnol. Biochem. 75, 23042308(2011).

19) Wanezaki, S.; Tachibana, N.; Nagata, M.; Nagao, K.; Yanagita, T.; Kohno M. Soy $\beta$-conglycinin improves obesity-induced metabolic abnormalities in a rat model of nonalcoholic fatty liver disease. Obese. Res. Clin. Pract. 9, 168-174(2015).

20) Nagata, Y.; Ishiwaki, N.; Sugano, M. Studies on the mechanism of antihypercholesterolemic action of soy protein and soy protein-type amino acid mixtures in relation to the casein counterparts in rats. J. Nutr. 112, 1614-1625 (1982).

21) Erdmann, K.; Cheung, B.W.; Schröder, H. The possible roles of food-derived bioactive peptides in reducing the risk of cardiovascular disease. J. Nutr. Biochem. 19, 643-654(2008).

22) Shahidi, F.; Zhong, Y. Bioactive peptides. J. AOAC Int. 91, 914-931 (2008).

23) Yoshikawa, M.; Fujita, H.; Matoba, N.; Takenaka, Y.; Yamamoto, T.; Yamauchi, R.; Tsuruki, H.; Takahata, K. Bioactive peptides derived from food proteins preventing lifestyle-related diseases. Biofactors 12, 143146 (2000).

24) Kodera, T.; Nio, N. Identification of an angiotensin Iconverting enzyme inhibitory peptides from protein hydrolysates by a soybean protease and the antihypertensive effects of hydrolysates in 4 spontaneously hypertensive model rats. J. Food Sci. 71, C164-C173 (2006).

25) Chen, H.M.; Muramoto, K.; Yamauchi, F.; Fujimoto, K.; Nokihara, K. Antioxidative properties of histidine-con- taining peptides designed from peptide fragments found in the digests of a soybean protein. J. Agric. Food Chem. 46, 49-53 (1998).

26) Nishi, T.; Hara, H.; Asano, K.; Tomita, F. The soybean beta-conglycinin beta 51-63 fragment suppresses appetite by stimulating cholecystokinin release in rats. $J$. Nutr. 133, 2537-2542(2003).

27) Kagawa, K.; Matsutaka, H.; Fukuhama, C.; Watanabe, Y.; Fujino, H. Globin digest, acidic protease hydrolysate, inhibits dietary hypertriglyceridemia and Val-ValTyr-Pro, one of its constituents, possesses most superior effect. Life Sci. 58, 1745-1755 (1996).

28) Folch, J.; Lee, M.; Sloane-Stanley, G.H. A simple method for the isolation and purification of total lipids from animal tissues. J. Biol. Chem. 226, 497-509(1957).

29) Fletcher, M.J. A colorimetric method for estimation of serum triglycerides. Clin. Chem. Acta 22, 393-397 (1968).

30) Rouser, G.; Siakotos, A.N.; Fleischer, S. Quantitative analysis of phospholipids by thin-layer chromatography and phosphorus analysis of spots. Lipids 1, 85-86 (1966).

31) Kelley, D.S.; Nelson, G.J.; Hunt, J.E. Effect of prior nutritional status on the activity of lipogenic enzymes in primary monolayer cultures of rat hepatocytes. Biochem. J. 235, 87-90 (1986).

32) Kelley, D.S.; Kletzien, R.F. Ethanol modulation of the hormonal and nutritional regulation of glucose 6-phosphate dehydrogenase activity in primary cultures of rat hepatocytes. Biochem. J. 217, 543-549 (1984).

33) Ochoa, S. Malic enzyme. in Merhods in Enzymology (Colowick, S.P.; Kaplan, N.O. eds.) Vol. 1, Academic Press, New York, NY, pp.739-753 (1955).

34) Markwell, M.A.; McGroarty, E.J.; Bieber, L.L.; Tolbert, N.E. The subcellular distribution of carnitine acyltransferases in mammalian liver and kidney. A new peroxisomal enzyme. J. Biol. Chem. 248, 3426-3432 (1973).

35) Lowry, O.H.; Rosebrough, N.J.; Farr, A.L.; Randall, R.J. Protein measurement with the Folin phenol reagent. $J$. Biol. Chem. 193, 265-275(1951).

36) Kawabeta, K.; Hase-Tamaru, S.; Yuasa, M.; Suruga, K.; Sugano, M.; Koba, K. Dietary $\beta$-conglycinin modulate insulin sensitivity, body fat mass, and lipid metabolism in obese Otsuka Long-Evans Tokushima Fatty (OLETF) rats. J. Oleo Sci. 68, 339-350 (2019).

37) Miettinen, T.A.; Gylling, H.; Nissinen, M.J. The role of serum non-cholesterol sterols as surrogate markers of absolute cholesterol synthesis and absorption. Nutr. Metab. Cardiovasc. Dis. 21, 765-769 (2011).

38) Gylling, H.; Hallikainen, M.; Simonen, P.; Miettinen, H.E.; Nissinen, M.J.; Miettinen, T.A. Serum and lipoprotein sitostanol and non-cholesterol sterols after an acute dose of plant stanol ester on its long-term con- 


\section{S. Wanezaki, S. Saito, N. Inoue et al.}

sumption. Eur. J. Nutr. 51, 615-622(2012).

39) Tsou, M.J.; Lin, S.B.; Chao, C.H.; Chiang, W.D. Enhancing the lipolysis-stimulating activity of soy protein using limited hydrolysis with Flavourzyme and ultrafiltration. Food Chem. 134, 1564-1570 (2012).

40) Singh, B.P.; Vij, S.; Hati, S. Functional significance of bioactive peptides derived from soybean. Peptides 54,
171-179 (2014).

41) Maebuchi, M.; Samoto, M.; Kohno, M.; Ito, R.; Koikeda, T.; Hirotsuka, M.; Nakabou, Y. Improvement in the intestinal absorption of soy protein by enzymatic digestion to oligopeptide in healthy adult men. Food Sci. Tech. Res. 13, 45-53(2007). 